\title{
BLOOD SERUM PROTEIN-BOUND CARBOHYDRATE AFTER INJURY
}

\author{
BY \\ J. W. KEYSER \\ From the Department of Pathology and Bacteriology, Welsh National School \\ of Medicine, Cardiff
}

(RECEIVED FOR PUBLICATION JULY 13, 1951)

In earlier publications (Keyser, 1949, 1950) we reported increases in the level of a substance giving the tryptophane-perchloric acid reaction (Cohen, 1944 ; Seibert, Pfaff, and Seibert, 1948) in the blood serum of six burn cases. No attempt was made at the time to identify the reacting substance, which is generally assumed to be a polysaccharide. The present investigation was undertaken to find out whether a rise in the level of serum protein-bound carbohydrate (protein sugar, non-glucosamine polysaccharide) after injury could be demonstrated by a more specific method and, if so, how much of it is contributed by the mucoprotein fraction studied by Winzler, Devor, Mehl, and Smyth (1948). It is possible that this mucoprotein fraction consists largely of the polypeptide-like substances occurring in trichloroacetic acid filtrates of serum (Hahn, 1921 ; Wolff, 1921) and precipitable therefrom by tungstic or phosphotungstic acid. The serum level of these polypeptides was reported to be raised after surgical operations and after burning (Cristol and Puech, 1929 ; Fiessinger, 1934 ; Goiffon and Spaey, 1934a, 1934b ; Duval, Roux, and Goiffon, 1934). For convenience the carbohydrate measured will be referred to as "protein sugar."

\section{Methods}

Blood was obtained by venepuncture, the serum being separated as soon as possible and kept frozen until the analyses were performed. In agreement with the findings of Seibert and Atno (1946), control experiments on two normal people showed no significant difference between the fasting and non-fasting levels of serum protein sugar, nor was the mucoprotein sugar significantly altered by feeding. Consequently no effort was made to obtain blood only in the fasting or non-fasting state. For the estimation of total serum protein sugar the proteins were separated by alcoholic precipitation as follows.

Serum, $1 \mathrm{ml}$., was added drop by drop to $19 \mathrm{ml}$. of absolute ethyl alcohol and the mixture shaken vigorously. The precipitated protein was spun down, the alcohol decanted, and the tube inverted and allowed to drain for a few minutes. The protein was then washed by boiling with two successive $10 \mathrm{ml}$. portions of $95 \%$ (by volume) ethyl alcohol, the precipitate being broken up and stirred with a fine glass rod during the process. After each washing the protein was spun down, the alcohol decanted, and the tube allowed to drain as before. Finally the protein was dissolved in $0.125 \mathrm{~N}$ sodium hydroxide to a volume of $10 \mathrm{ml}$. One portion $(1$ or $2 \mathrm{ml}$.) of the alkaline protein solution was taken for Kjeldahl digestion. Duplicate $0.5 \mathrm{ml}$. portions were taken for analysis by the orcinol method (Tillmans and Philippi, 1929 ; Sxrensen and Haugaard, 1933), 
essentially as described by Rimington (1940). Care was taken to avoid exposure to light during and after the heating. No attempt was made to carry out a protein "blank" by heating with sulphuric acid in the absence of orcinol, since it has been shown (Sørensen, 1936 ; Hewitt, 1937) that the slightly coloured solutions obtained in this way do not represent true blanks and are a source of error. Reagent blanks were performed. A standard calibration curve, prepared with a solution of equal parts by weight of galactose and mannose, was checked at frequent intervals.

Mucoprotein was estimated by the method of Winzler, Devor, Mehl, and Smyth (1948). To $2 \mathrm{ml}$. of serum $8 \mathrm{ml}$. of $0.75 \mathrm{M}$ perchloric acid was added and the mixture vigorously shaken. After 10 minutes the precipitated proteins were filtered off with a Whatman No. 50 filter paper $(9 \mathrm{~cm}$.). The mucoprotein was precipitated from duplicate $2 \mathrm{ml}$. portions of the filtrate by the addition of $0.4 \mathrm{ml}$. of a $5 \%$ solution of phosphotungstic acid in $2 \mathrm{~N}$ hydrochloric acid, and spun down after 15 minutes. The precipitate was washed first with $1 \mathrm{ml}$. of the phosphotungstic acid solution and then with $2 \mathrm{ml}$. of $95 \%$ (by volume) ethyl alcohol, being thoroughly broken up and stirred with a fine glass rod in each washing. The mucoprotein was finally dissolved in $0.5 \mathrm{ml}$. of $0.125 \mathrm{~N}$ sodium hydroxide for analysis by the orcinol method.

\section{Results}

The findings are summarized in Table I. Normal values for total serum protein sugar and mucoprotein sugar found in this laboratory are given in Table II, and are mostly in the range of published figures. It is evident that after injury there was a considerable rise in the concentration of both total protein sugar and mucoprotein sugar. The rise in the former is in accord with the observations of Shetlar, Bryan, Foster, Shetlar, and Everett (1949), which came to my notice while the present work was in progress. They found that experimental injury to animals (e.g., the production of sterile abscesses, laparotomy, and so on) resulted in a more or less pronounced rise in the serum polysaccharide level, as measured by a tryptophane method (Sheppard and Everett, 1937 ; Shetlar, Foster, and Everett, 1948). They do not appear, however, to have estimated the mucoprotein fraction.

The mucoprotein figures shown in Tables I and II are almost certainly lower than the true values, as it has been shown by Winzler and his colleagues that considerable amounts of mucoprotein are adsorbed on the precipitate obtained when perchloric acid is added to serum. These losses are smallest when the serum proteins are lowered. In our cases the serum proteins (Table I) were not sufficiently lowered to account for the high mucoprotein values found. It is interesting to note that the proportion of the total increase in protein sugar contributed by the mucoprotein fraction varied considerably and clearly tended to be highest when the total protein sugar was only slightly raised. Indeed, the mucoprotein sugar was sometimes raised when the total protein sugar was within normal limits. This has been found also in an investigation (to be published) of patients treated with nitrogen mustard or by radiation therapy.

In all but one of our cases the tryptophane-perchloric acid reaction was also carried out : it parallelled roughly the total protein sugar.

\section{Discussion}

These results confirm and extend those previously obtained by us with the tryptophane-perchloric acid method, which were doubtless due to a rise in the serum protein sugar. 
TABLE I

Total Protein and Mucoprotein Sugar in Burns and Fractures

\begin{tabular}{|c|c|c|c|c|c|c|c|}
\hline $\begin{array}{c}\text { Case } \\
\text { No. }\end{array}$ & Age & Sex & $\begin{array}{l}\text { Type of } \\
\text { Injury }\end{array}$ & $\begin{array}{l}\text { Days } \\
\text { after } \\
\text { Injury }\end{array}$ & $\begin{array}{c}\text { Total } \\
\text { Serum Protein } \\
\text { (g. } / 100 \mathrm{ml} .)\end{array}$ & $\begin{array}{c}\text { Total Serum } \\
\text { Protein Sugar } \\
\text { as Galactose- } \\
\text { mannose } \\
(\mathrm{mg} . / 100 \mathrm{ml} .)\end{array}$ & $\begin{array}{c}\text { Serum } \\
\text { Mucoprotein } \\
\text { Sugar as } \\
\text { Galactose- } \\
\text { mannose } \\
\text { (mg. } / 100 \mathrm{ml} .)\end{array}$ \\
\hline 1 & 23 & M. & $\begin{array}{l}\text { Burns and } \\
\text { fractures }\end{array}$ & $\begin{array}{r}2 \\
4 \\
10 \\
26 \\
81 \\
199\end{array}$ & $\begin{array}{l}6 \cdot 1 \\
5 \cdot 9 \\
5 \cdot 8 \\
6 \cdot 4 \\
7 \cdot 0 \\
-\end{array}$ & $\begin{array}{l}115 \\
160 \\
232 \\
220 \\
142 \\
126\end{array}$ & $\begin{array}{l}\overline{41} \\
64 \\
54 \\
21 \\
18\end{array}$ \\
\hline 2 & $10 / 12$ & M. & Burns & 3 & $6 \cdot 3$ & 143 & 22 \\
\hline 3 & 47 & M. & Burns & $\begin{array}{l}1 \\
7\end{array}$ & $\begin{array}{l}6 \cdot 1 \\
5 \cdot 9\end{array}$ & $\begin{array}{l}156 \\
186\end{array}$ & $\overline{45}$ \\
\hline 4 & 27 & M. & Burns & $\begin{array}{l}1 \\
7\end{array}$ & $\begin{array}{l}6 \cdot 5 \\
7 \cdot 1\end{array}$ & $\begin{array}{l}148 \\
186\end{array}$ & $\overline{31}$ \\
\hline 5 & 76 & $\mathrm{~F}$. & Fracture & 4 & $7 \cdot 0$ & 170 & 26 \\
\hline 6 & 54 & M. & Fracture & $\begin{array}{l}12 \\
22\end{array}$ & $\begin{array}{l}6 \cdot 3 \\
7 \cdot 1\end{array}$ & $\begin{array}{l}155 \\
141\end{array}$ & $\begin{array}{l}22 \\
19\end{array}$ \\
\hline 7 & $17 \frac{1}{2}$ & $\mathrm{~F}$. & Fracture & $\begin{array}{l}1 \\
5\end{array}$ & $\begin{array}{l}6 \cdot 7 \\
7 \cdot 4\end{array}$ & $\begin{array}{l}132 \\
221\end{array}$ & $\begin{array}{l}16 \\
26\end{array}$ \\
\hline 8 & 79 & $\mathrm{~F}$. & Fracture & $\begin{array}{l}5 \\
9\end{array}$ & $\begin{array}{l}5 \cdot 5 \\
6 \cdot 3\end{array}$ & $\begin{array}{l}134 \\
164\end{array}$ & $\begin{array}{l}21 \\
23\end{array}$ \\
\hline 9 & 52 & M. & Fracture & $\begin{array}{l}10 \\
17\end{array}$ & $\begin{array}{l}6 \cdot 8 \\
6 \cdot 0\end{array}$ & $\begin{array}{l}160 \\
140\end{array}$ & $\begin{array}{l}25 \\
18\end{array}$ \\
\hline 10 & 70 & F. & Fracture & 59 & $6 \cdot 6$ & 146 & 18 \\
\hline
\end{tabular}

TABLE II

Total Serum Protein and Mucoprotein Sugar in Normals

\begin{tabular}{|c|c|c|c|c|c|}
\hline & & & & $\begin{array}{l}\text { Total Serum Protein } \\
\text { Sugar* (18 people) }\end{array}$ & $\begin{array}{l}\text { Mucoprotein Sugar* } \\
\text { (13 people) }\end{array}$ \\
\hline $\begin{array}{ll}\text { Range } & . \\
\text { Mean } & \text {. } \\
\text { Standard deviation }\end{array}$ & $\begin{array}{ll}\cdots & \ldots \\
\cdots & . . \\
& \ldots\end{array}$ & $\begin{array}{l}\cdots \\
\cdots \\
\cdots\end{array}$ & \begin{tabular}{l|l}
$\ldots$ \\
$\ldots$ \\
$\cdots$
\end{tabular} & $\begin{array}{c}102-139 \\
119 \\
12\end{array}$ & $\begin{array}{c}10 \cdot 0-13 \cdot 0 \\
11 \cdot 9 \\
1.2\end{array}$ \\
\hline
\end{tabular}

* As mg. galactose-mannose per $100 \mathrm{ml}$. serum.

It seems likely that the increases in serum $\alpha$-globulin reported by various workers after experimental burning in animals (Perlmann, Glenn, and Kaufman, 1943; Chanutin and Gjessing, 1946) and in human burns and fracture cases (Shedlovsky and Scudder, 1942) are due, in part at least, to the mucoprotein fraction (cf. electrophoretic data of Mehl, Humphrey, and Winzler, 1949 ; Mehl, Golden, and Winzler, 1949 ; and Petermann and Hogness. 1948). 
Seibert and her colleagues (Seibert, Pfaff, and Seibert, 1948 ; Seibert, Seibert, Atno, and Campbell, 1947) have suggested that elevation of serum polysaccharide is associated with tissue destruction. An alternative hypothesis is that it is associated with healing processes or proliferation (Shetlar, Bryan, Foster, Shetlar, and Everett, 1949 ; Shetlar, Erwin, and Everett, 1950 ; Shetlar, Foster, Kelly, Shetlar, Bryan, and Everett, 1949). Although our findings are consistent with the "tissue destruction" hypothesis, the prolonged elevation of total protein sugar and mucoprotein sugar in Case 1 would suggest some connexion with healing. (It must be emphasized that the destruction we have in mind is not merely that due to local trauma, but is rather the general metabolic response to injury implied in the wellknown conception of a katabolic phase of negative nitrogen balance, and implied also in the suggestion of Croft and Peters (1945) that after burning there is a "raiding " of the tissue proteins for one or two amino acids particularly needed for the formation of new skin protein.) However, this prolonged elevation might have been due partly to skin-grafting necessitated by the presence of unhealed areas, though the burn itself was completely healed by the forty-second day after the injury. Unfortunately it was not practicable to study the other cases for more than a few days. As far as could be ascertained Cases 5 to 10 were completely afebrile and the majority of all our cases were uncomplicated by the presence of disease.

Apart from the hypotheses mentioned above, it might be that after injury there is a retention of carbohydrate-rich protein fractions or a failure to metabolize them. This possibility cannot at present be excluded.

\section{Summary}

A study of 10 cases of burns and fractures revealed a well-marked rise in the blood serum protein-bound and mucoprotein-bound carbohydrate (protein sugar, non-glucosamine polysaccharide) after injury. In one patient who was followed up for several months the total protein sugar and mucoprotein sugar reached a maximum several days after injury; but whereas the total protein sugar had fallen to normal levels after 11 weeks, the mucoprotein sugar was still high after 28 weeks.

I wish to thank the many people who helped me to obtain blood specimens, and the surgeons who allowed me to study their cases. I am grateful also to Professor J. Gough for his help and encouragement.

\section{REFERENCES}

Chanutin, A., and Gjessing, E. C. (1946). J. biol. Chem., 165, 421.

Cohen, S. S. (1944). Ibid., 156, 691.

Cristol, P., and Puech, A. (1929). Cited by Goiffon and Spaey, 1934.

Croft, P. B., and Peters, R. A. (1945). Lancet, 1, 266.

Duval, P., Roux, J.- C., and Goiffon, R. (1934). Pr. méd., 42, 1785.

Fiessinger, N. (1934). Ibid., 42, 1787.

Goiffon, R., and Spaey, J. (1934a). Bull. Soc. Chim. biol., 16, 1675.

(1934b). C.R. Soc. Biol., Paris, 115, 711.

Hahn, A. (1921). Biochem. $Z$., 121, 262.

Hewitt, L. F. (1937). Biochem. J., 31, 360.

Keyser, J. W. (1949). Nature, Lond., 164, 889. (1950). Journal of Clinical Pathology, 3, 106.

Mehl, J. W., Golden, F., and Winzler, R. J.(1949). Proc. Soc. exp. Biol., N.Y., 72, 110.

Humphrey, J., and Winzler, R. J. (1949). Ibid., 72, 106.

Perlmann, G. E., Glenn, W. W. L., and Kaufman, D. (1943). J. clin. Invest., 22, 627. 
Petermann, M. L., and Hogness, K. R. (1948). Cancer, 1, 100, 104.

Rimington, C. (1940). Biochem. J., 34, 931.

Seibert, F. B., and Atno, J. (1946). J. biol. Chem., 163, 511.

Pfaff, M. L., and Seibert, M. V. (1948). Arch. Biochem., 18, 279.

- Seibert, M. V., Atno, A. J., and Campbell, H. W. (1947). J. clin. Invest., 26, 90.

Shedlovsky, T., and Scudder, J. (1942). J. exp. Med., 75, 119.

Sheppard, F., and Everett, M. R. (1937). J. biol. Chem., 119, lxxxix.

Shetlar, M. R., Bryan, R. S., Foster, J. V., Shetlar, C. L., and Everett, M. R. (1949). Proc. Soc. exp. Biol., N.Y., 72, 294.

Erwin, C. P., and Everett, M. R. (1950). Cancer Res., 10, 445.

- Foster, J. V., and Everett, M. R. (1948). Proc. Soc. exp. Biol., N.Y., 67, 125. Kelly, K. H., Shetlar, C. L., Bryan, R. S., and Everett, M. R. (1949). Cancer Res., 9, 515.

Sørensen, M. (1936): Biochem. Z., 287, 140. and Haugaard, G. (1933). Ibid., 260, 247.

Tillmans, J., and Philippi, K. (1929). Ibid., 215, 36.

Winzler, R. J., Devor, A. W., Mehl, J. W., and Smyth, I. M. (1948). J. clin. Invest., 27, 609.

Wolff, E. (1921). Ann. Méd., 10, 185. 